Оригинальная статья/Original article

УДК 001.5631.576.331.2:633.11

DOI: http://doi.org/10.20914/2310-1202-2017-1-205-208

\begin{tabular}{c}
\hline \hline Влияние факторов на формирование технологического потенциала \\
зерна мягкой пшеницы \\
\hline \hline
\end{tabular}

$\frac{\text { Даригаш А. Шаймерденова } 1 \text { darigash@mail.ru }}{\text { 1 ТОО «Казахский научно-исследовательский институт переработки сельскохозяйственной продукции», ул. Акжол, 26, г. Астана, }}$
010000, Казахстан

Реферат. Технологический потенциал (ТП) зерна мягкой пшеницы, позволяющий получать огромное количество востребованных человечеством продуктов, является основным фактором его широкого распространения. Формирование ТП с заданными свойствами является одной из важнейших задач для специалистов, работающих с зерном мягкой пшеницы на всех этапах его жизненного цикла - специалистов сельского хозяйства на этапах селекции, выращивания и уборки, технологов на этапах послеуборочной обработки, хранения и переработки. Предложен системный подход к процессу формирования и повышения ТП, позволяющий объективно оценить вклад факторов и возможность влияния на каждом этапе на конечный результат. В систему формирования ТП зерна мягкой пшеницы предложено включить следующие 8 подсистем: «природно-климатические условияТП»; «почвенные условия ТП»; «предшественник ТП»; «сортовые особенности ТП»; «технологии уборки ТП»; «технологии послеуборочной обработки ТП»; «методы оценки технологического достоинства ТП»; «технологии хранения ТП». Исследования позволили установить, что из рассматриваемых 8 подсистем подсистемы «почвенные условия - ТП» и «технологии уборки ТП» оказали нулевое воздействие на повышение ТП, что согласуется с данными исследований Института селекции зерновых культур, которые определили, что из следующих факторов - предшественник, сроки посева, нормы посева, нормы азотных удобрений, фунгицидные обработки посевов тилтом 250 ЕС и протравливание семян байтаномкомби и т.д., качество обусловлено только сортовыми особенностями, годом выращивания и предшественником. Для определения степени воздействия остальных рассмотренных подсистем методом дисперсионного анализа определена доля влияния каждой подсистемы как фактора воздействия на формирование ТП зерна мягкой пшеницы.

Ключевые слова: мягкая пшеница, технологический потенциал, показатели, технологическое достоинство, системный подход, фактор, доля влияния

\title{
Influence factors on the formation of technological capabilities of grain soft wheat
}

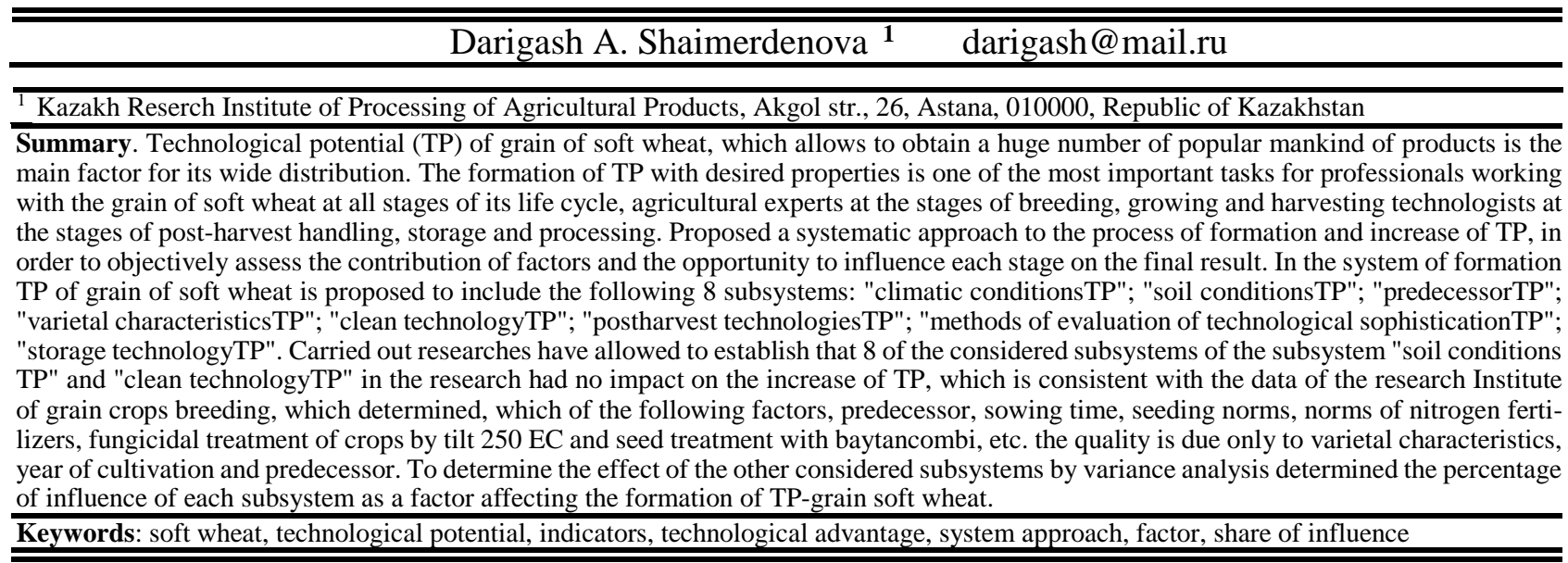

\section{Введение}

В проведенных ранее разными авторами исследованиях рассматривалось влияние на технологический потенциал зерна мягкой пшеницы единичных факторов, иногда принималось во внимание несколько факторов одновременно. Так, в исследованиях В.В. Келера [6], Ю.Н. Титова, Ф.М. Стрижова [11], С.И. Пряхина и др. [7], Н.А. Зверева и др.[3], Г.Н. Сандаковой [8] изучалось влияние на урожай и качество зерна пшеницы почвенно-климатических условий регионов произрастания. В работах А.И. Бараева [1], C.C. Синицына [10], Сандаковой Г.Н., Для цитирования

Шаймерденова Д.А. Влияние факторов на формирование технологического потенциала зерна мягкой пшеницы // Вестник ВГУИТ.2017. Т. 79. № 1. C. 205-208. doi:10.20914/2310-1202-2017-1-205-208
А.Г. Крючкова [9] рассматривалось влияние нескольких факторов - почвенно-климатических факторов, агротехнологических приемов; C.M. Дашкевич [2] изучала влияние также сортовых особенностей.

Рассматривать формирование ТП зерна пшеницы как целостную систему, включающую этапы вегетации, уборки, послеуборочной обработки, хранения, предложил А.И. Изтаев [4]. Однако оценка степени влияния каждого компонента системы, что позволило бы в определенной степени влиять на процесс формирования ТП зерна мягкой пшеницы, не проводилась.

\section{For citation}

Shaimerdenova D.A. Influence factors on the formation of technological capabilities of grain soft wheat. Vestnik VGUIT [Proceedings of VSUET]. 2017. vol. 79. no. 1. pp. 205-208. (in Russian). doi:10.20914/2310-1202-2017-1-205-208 


\section{Материалы и методы}

Для определения технологического потенциала зерна мягкой пшеницы по формуле, предложенной в предыдущих исследованиях [13], была разработана программа языком Code: Blocks, позволяющая рассчитать значение ТП для зерна с разными значениями ТД при их нормированных показателях. Определение ТП 144 образцов зерна мягкой пшеницы урожая 2010 года позволило установить градации по ТП для зерна мягкой пшеницы (таблица 1). Далее были проведены исследования по определению показателя ТП в различных подсистемах: «природноклиматические условия ТП»; «предшественник ТП»; «сортовые особенности ТП»; «технологии послеуборочной обработки ТП»; «методы оценки технологического достоинства ТП»; «технологии хранения ТП» и методом дисперсионного анализа установлена доля влияния каждой подсистемы в системе формирования ТП. Показатели ТД определялись общепринятыми методами, описанными в нормативно-методических документах (ГОСТах (межгосударственных стандартах), СТ РК (стандартах Республики Казахстан). Математическая обработка результатов исследований проводилась методом корреляционного и регрессионного анализа с использованием прикладных программ Excel и Stadia.

\section{Результаты и их обсуждение}

Определение ТП 144 образцов зерна мягкой пшеницы позволил провести градацию зерна мягкой пшеницы по показателю ТП (таблица 1).

Далее были проведены эксперименты и установлены показатели ТД во всех принятых подсистемах. По полученным показателям ТД были рассчитаны показатели ТП (таблица 2).

Для определения доли влияния каждой подсистемы были рассчитаны групповые и общие дисперсии, так как доля участия отдельных факторов в формировании результативного признака определяется из отношения групповых дисперсий к общей(в процентах):

$$
\eta \text { (доля) }=\mathrm{C}_{\phi} / \mathrm{C}_{\mathrm{o}}
$$

где $\eta$ (доля) - доля участия фактора; $C_{\phi}-$ дисперсия факториальная; $C_{o}$ - дисперсия общая.

Определение доли влияния факторов на формирование ТП позволило установить, что наибольшее влияние на формирование ТП имеют сортовые особенности зерна мягкой пшеницы - 28,4\% (таблица 3).

Таблица 1.

Table 1.

Gradation of grain of soft wheat in terms of TP

\begin{tabular}{|l|l|}
\hline Значение ТП & Характеристика зерна | Characteristic grain \\
The value of TP & Показатели ТД в пределах нормированных значений \\
\hline Oт 0,70 до 3,00 & Indicators of ТD in the range of normalized values \\
Ranging from 0.70 to 3.00 & Показатели ТД значительно ниже нормированных значений \\
\hline $\begin{array}{l}\text { Oт } 0,20 \text { до } 0,70 \\
\text { Ranging from } 0.20 \text { to } 0,70\end{array}$ & Indicators of TD is significantly lower normalized values \\
\hline 0т 3,00 до 5,00 & Показатели TД значительно превышают нормированные значения \\
Ranging from 3,00 to 5,00 & Indicators of TD considerably exсеeds the normalized value \\
\hline
\end{tabular}

Таблица 2.

Изменение комплексного показателя ТП в системе повышения технологического потенциала

Table 2.

The change in the complex index of TP in the system of improvement of technological capabilities

\begin{tabular}{|c|c|c|c|c|c|}
\hline \multicolumn{7}{|c|}{$\begin{array}{c}\text { Прдсистемы } \\
\text { тические условияstems } \\
\text { Climatic conditions }\end{array}$} & $\begin{array}{c}\text { Предшест- } \\
\text { венник } \\
\text { Predecessor }\end{array}$ & $\begin{array}{c}\text { Сортовые } \\
\text { особенности } \\
\text { Features varie- } \\
\text { ties of grain }\end{array}$ & $\begin{array}{c}\text { Технологии после- } \\
\text { уборочной обработки } \\
\text { Post-harvest } \\
\text { technologies }\end{array}$ & $\begin{array}{c}\text { Методы } \\
\text { оценки Тд } \\
\text { Methods of eval- } \\
\text { uation of TD }\end{array}$ & $\begin{array}{c}\text { Технологии } \\
\text { хранения } \\
\text { Storage technology }\end{array}$ \\
\hline 1,41 & 2,15 & 2,38 & 1,28 & 0,19 & 1,77 \\
\hline 0,48 & 1,69 & 0,94 & 0,9 & 1,42 & 1,85 \\
\hline 1,37 & 1,76 & 2,83 & 0,97 & 0,51 & 1,75 \\
\hline 1,24 & 1,77 & 1,48 & 1,15 & 0,51 & 1,82 \\
\hline 0,44 & 2,33 & 2,06 & 1,86 & 1,41 & 1,54 \\
\hline 0,55 & 1,26 & 1,04 & 0,89 & 1,63 & 1,64 \\
\hline 3,02 & 1,74 & 0,84 & 0,65 & 1,45 & 1,82 \\
\hline 0,34 & 1,29 & 1,47 & 1,32 & 1,72 & 1,38 \\
\hline 1,09 & 1,53 & 2,26 & 1,17 & 1,2 & 1,7 \\
\hline 1,06 & 1,57 & 0,94 & 1,04 & 1,86 & 1,38 \\
\hline
\end{tabular}


The proportion of the influence of subsystems on the formation of TP

\begin{tabular}{|l|c|}
\hline \multicolumn{1}{|c|}{ Подсистема | Subsystem } & \multicolumn{1}{|c|}{$\begin{array}{c}\text { Доля влияния, \% } \\
\text { Share of influence, \% }\end{array}$} \\
\hline «Природно-климатические условия ТП»| “Climaticconditions ТР” & 14,2 \\
\hline «Предшественник ТП» | "Predecessor - ТР" & 9,6 \\
\hline $\begin{array}{l}\text { «Сортовые особенности ТП» } \\
\text { Features varieties of grain }\end{array}$ & 28,4 \\
\hline «Технологии послеуборочной обработки ТП»| Post-harvesttechnologies & 9,2 \\
\hline «МетодыоценкиТД ТП» | Methods of evaluation of ТD & 20,9 \\
\hline «Технологии хранения ТП» | Storage technology & 2,7 \\
\hline Общая сумма | The total amount of & 85 \\
\hline Случайные факторы | Random factors & 15 \\
\hline
\end{tabular}

Следом за сортовыми особенностями наиболее значительное воздействие на формирование ТП оказывает подсистема «методы оценки ТД ТП», далее подсистема «природно-климатические условия ТП». Наименьшее воздействие на формирование ТП оказала подсистема «технологии хранения ТП».

\section{Заключение}

Наибольшее влияние на формирование ТП имеют сортовые особенности зерна мягкой пшеницы, ввиду чего следует в дальнейшем провести исследования по определению наиболее высокопродуктивных сортов мягкой пшеницы для получения высокого ТП.

Следующей по значимости на формирование ТП зерна мягкой пшеницы определена подсистема «методы оценки ТД ТП», из чего

\section{ЛИТЕРАТУРА}

1 Бараев А.И. Яровая пшеница в Северном Казахстане. Алма-Ата: Кайнар, 1976.

2 Дашкевич С.М. Качество зерна, смесительная ценность и адаптивность сортов яровой мягкой пшеницы Северного Казахстана: дис. ... канд. с.-х. наук. Шортанды, 2007.

3 Зверева Н.А., Терехин М.В., Мищенко Л.Н. Влияние погодных условий и природной зоны возделывания на качество зерна яровой пшеницы в Амурской области // Вестник Алтайского государственного аграрного университета. 2013 № 4 (102). С. 10-13.

4 Изтаев А.И. Совершенствование послеуборочной обработки зерна пшеницы в условиях Казахстана: дис. ... д-р тех. наук. М., 1992.

5 Казаков Е.Д., Карпиленко Г.П. Пути совершенствования качества зерна // Известия ВУЗов. Пищевая технология. 1995. № 1-2. С. 19-23

6 Келер В.В. Влияние гидротермических условий на формирование белка районированных сортов яровой пшеницы в лесостепной зоны Красноярского края // Вестник КрасГАУ, Почвоведение и растениеводство. 2008. № 1. С. 56-59.

7 Пряхина С.И., Скляров Ю.А., Васильева М.Ю. Агрометеорологические прогнозы качества зерна озимой и яровой пшеницы в Саратовской области // Известия Саратовского университета. 2007. Т. 7. С. 26-29. следует необходимость исследований по разработке методов и способов оценки ТД.

По подсистеме «природно-климатические условия ТП» необходимо определить возможные благоприятные природно-климатические условия для получения зерна мягкой пшеницы с высоким ТП.

Изучение воздействия на формирование ТП предшественников позволит предложить наиболее благоприятно влияющие на повышение ТП предшественников при производстве зерна пшеницы.

Следует исследовать и разработать эффективные технологии послеуборочной обработки зерна пшеницы, что позволит повысить ТП свыше 9\%.

Технологии хранения мягкой пшеницы, разработанные с учетом состояния хранящегося зерна, позволят повысить ТП до 3\%.

8 Сандакова Г.Н. Динамика погодных факторов и их вероятность для формирования зерна яровой сильной пшеницы с высоким содержанием клейковины в центральной зоне Оренбурской области // Известия Оренбургского государственного аграрного унивеститета. 2016. № 5 (61).

9 Сандакова Г.Н., Крючков А.Г. Научнообоснованные параметры моделей формирования высокобелкового и высоконатурного зерна сильной пшеницы в условиях Оренбургского Предуралья в зависимости от погодных условий и агротехнических приемов возделывания. Оренбург, 2014. 86 с.

10 Синицын С.С. Основные пути повышения технологического качества зерна мягкой пшеницы Северного Казахстана //Приемы и методы повышения качества колосовых культур. 1967.

11 Титов Ю.Н., Стрижова Ф.М. Влияние почвенно-климатических условий на реакцию сортов по содержанию белка // Вестник Алтайского государственного аграрного университета. 2007. № 10 (36). С. 28-32.

12 Шаймерденова Д.А., Изтаев А.И. Разработка системы формирования технологического потенциала зерна мягкой пшеницы. Продовольственная безопасность: научное, кадровое и информационное обеспечение // Матер. III Междунар. науч.-техн. конф. / Воронеж. гос. ун-т инж. технол. Воронеж: ВГУИТ, 2016. С. 422-426. 
13 Шаймерденова Д.А. Комплексный показатель технологического потенциала зерна мягкой яровой пшеницы. Продовольственная безопасность: научное, кадровое и информационное обеспечение // Матер. III Междунар. науч.-техн. конф. / Воронеж. гос. ун-т инж. технол. Воронеж: ВГУИТ, 2016. С. 431-436

\section{REFERENCES}

1 Barayev A.I. Yarovaya pshenitsa v Severnom Kazakhstane [Spring wheat in Northern Kazakhstan] Alma-Ata, Kaynar, 1976. (in Russian)

2 Dashkevich S.M. Kachestvo zerna, smesitel'naya tsennost' I adaptivnost' [Quality of grain, mixing value and adaptability of varieties of spring soft wheat of Northern Kazakhstan] Shortandy, 2007. (in Russian)

3 Zvereva N.A., Terekhin M.V., Mishchenko L.N. Influence of weather conditions and natural areas of cultivation on grain quality of spring wheat in the Amur region. Vestnik AltGAU [Bulletin of Altai state agrarian University] 2013, no. 4 (102). pp. 10-13. (in Russian)

4 Iztayev A.I. Sovershenstvovanie posleuborochnoi obrabotki [Improving post-harvest handling of wheat in Kazakhstan] Moscow, 1992. (in Russian)

5 Kazakov E.D., Karpilenko G.P. Ways of improving grain quality. IzvestiyaVuzov. [University news. Food technology] 1995, no. 1-2, pp. 19-23 (in Russian)

6 Koehler V.V. The Influence of gidrotermical conditions on the formation of protein cultivars of spring wheat in forest-steppe zone of the Krasnoyarsk territory. Vestnik KrasGAU. [Proceedings of Kras SAU. Soil science and crop production] 2008, no. 1, pp. 56-59. (in Russian)

7 Pryakhin S.I, Sklyarov Yu. A., Vasiliev M. $\mathrm{Yu}$. Agrometeorologycal predictions of grain quality of winter and spring wheat in Saratov region. Izvestiya Saratovskogo universiteta [News of Saratov University] 2007. vol. 7. pp. 26-29. (in Russian)

\section{СВЕДЕНИЯ ОБ АВТОРАХ}

Даригаш А. Шаймерденова к.т.н., ученый секретарь, Казахский научно-исследовательский институт переработки сельскохозяйственной продукции, ул. Акжол, 26, г. Астана, 010000, Казахстан, darigash@mail.ru

\section{КРИТЕРИЙ АВТОРСТВА}

Даригаш А. Шаймерденова написала рукопись и несёт ответственность за плагиат

КОНФЛИКТ ИНТЕРЕСОВ

Автор заявляет об отсутствии конфликта интересов.

ПОСТУПИЛА 01.04.2017

ПРИНЯТА В ПЕЧАТЬ 01.05.2017
8 Sandakova G.N. The dynamics of weather factors and their probability for the formation of a strong grain of spring wheat with high gluten content in the Central zone of the Orenburg region. Izvestiya Orenburgskogo GAU [News of the Orenburg state agricultural University] 2016. no. 5 (61). (in Russian)

9 Sandakova G.N., Kryuchkov A.G. Nauchnoobosnovannye parametry modelei formirovaniya vysokobelkovogo syr'ya [Evidence-based parameters for models of the formation of the high-protein and high-field strong grain of wheat in the conditions of the Orenburg Ural region, depending on weather conditions and agrotechnical methods of cultivation] Orenburg, 2014. 86 p. (in Russian)

10 Sinitsyn S.S. The main ways to enhance technological properties of grain of soft wheat of Northern Kazakhstan. Priemy I metody povysheniya kachestva kolosovykh kul'tur [Techniques and methods of quality improvement of cereals] 1967. (in Russian)

11 Titov Yu. N., Strizhova F.M. The Influence of soil and climatic conditions for the reaction of the cultivars according to protein content. Vestnik AltGAU [Bulletin of Altai state agrarian University] 2007. no. 10 (36). pp. 28-32. (in Russian)

12 Shaimerdenova D.A., Iztayev A.I. System development formation of technological potential of grain of soft wheat. Food security: scientific, personnel and information security. Materialy III mezhdunar. nauch.tekh. konf. [Mater. III Intern. scientific.-tech. Conf.] Voronezh, VSUET, 2016. pp. 422-426. (in Russian)

13 Shaimerdenova D.A. Integrated indicator of the technological potential of grain of soft spring wheat. Pro-food security: scientific, personnel and information security Materialy III mezhdunar. nauch.-tekh. konf. [Mater. III Intern. scientific.-tech. Conf.] Voronezh, VSUET, 2016. pp. 431-436 (in Russian)

\section{INFORMATION ABOUT AUTHORS}

Darigash A. Shaimerdenova candidate of technical sciences, scientific secretary, Kazakh research Institute of processing of agricultural products, Akzhol str. 26, Astana, 010000, Kazakhstan, darigash@mail.ru

\section{CONTRIBUTION}

Darigash A. Shaimerdenova wrote the manuscript and is responsible for plagiarism

\section{CONFLICT OF INTEREST}

The author declare no conflict of interest. RECEIVED 4.1.2017

ACCEPTED 5.1.2017 